\title{
Development of Assessment Instrument for Singing Skills and Playing Musical Instrument for The Music Teacher Candidates of General Schools
}

\author{
Udi Utomo ${ }^{\bowtie}$, Abdul Rachman, Moch. Usman Wafa \\ Department of Drama, Dance, and Music, Faculty of Languages and Arts, \\ Universitas Negeri Semarang, Indonesia
}

Received: September 19, 2019. Revised: November 6, 2019. Accepted: December 29, 2019

\begin{abstract}
The competences of music teacher candidates in teaching singing practice and playing a musical instrument are needed in the teaching-learning process at general schools. Hence, the process needs a comprehensive preparation for both competences. The objective of this study is to prepare an assessment instrument of singing practice and playing a musical instrument which is needed to assess the competences of music teacher candidates. The study used mix-method approach. The combination of qualitative and quantitative is required as the two methods are interrelated for both in the process of preparing assessment instruments and testing the instrument. The instruments consist of nine assignments. The six of which are the instruments for reading melodic and rhythmic notation and the other three instruments are to assess the skills to accompany songs. Based on the result, it can be found that the coefficient of instrument reliability is 0.817 in the type of consistency definition and 0.810 in the type of absolute agreement definitions. It can be concluded that the instrument made by using the analytic rubric of coefficient the reliability is better compared to the instrument made by a holistic rubric.
\end{abstract}

Keywords: Assessment; Skills; Singing; Playing Musical Instrument

How to Cite: Utomo, U., Rachman, A. \& Wafa, M. U. (2019). Development of Assessment Instrument for Singing Skills and Playing Musical Instrument for The Music Teacher Candidates of General Schools. Harmonia: Journal of Arts Research And Education, 19(2), 185-192.

\section{INTRODUCTION}

Improving the quality of education as an effort to pursue progress and face global competition at this time is an inevitable demand for our nation. Education quality improvement can be done through three pillars of education, namely through regulatory aspects (curriculum), professional aspects (teachers), and education management aspects. Through the regulatory aspect, improving the quality of education is done by emphasizing aspects of curricu- lum improvement, while the professional aspect is done through the development of the teaching profession. Furthermore, through the education management aspects, efforts to improve the quality of education are carried out by developing the role of decision-making centers and educational control at a level closer to the teaching-learning process (Zamroni, 2000). Efforts to develop the professionalism of teachers have basically started when teacher candidates take education (pre-service) and continue when teachers

\footnotetext{
Corresponding author:

E-mail: udiutomo@mail.unnes.ac.id
} 
occupy these positions (in-service). In the context of education, the implementation strategy is carried out both through improvements in content standards, process standards, and assessment standards. Related to the assessment problem, adjusting the model and content of the teacher competency standard assessment as a consequence of an outcome needs to be done (Fitzsimons, 1997). For example in the United States in the interests of education accreditation NCATE (National Council for Accreditation of Teacher Education) has revised existing standards into a new standard that emphasizes aspects of knowledge and practice, performance, new forms of assessment, inter-school collaboration, technology, and the diversity of program evaluations in various contexts on an ongoing basis. In a different context, there is also an example that in New Zealand the enforcement of teacher competency standards includes efforts to (1) assist the government in the management of education; (2) teacher assessment; (3) improvement of instructors, and (4) improvement in student achievement standards and quality of learning.

Previous studies have shown that learning music in public schools is not entirely as expected. The use of teachercentered lecture and drill methods is still very dominant, so it does not prepare students to develop critical, appreciative, creative, imaginative, and innovative abilities that support further education and life in society (Yoseph, 2009; Sinaga et al., 2010). In order for the implementation of music learning in schools to be a meaningful process for students, the implementation must be done through musical experience. As a form, every form of learning activity must be carried out through integrated activities that include musical activities as one of its components (action learning). These musical activities can be in the form of listening to music, responding to music with rhythmic movements, singing, reading music notation, playing musical instruments, creating music, analyzing music, recording music and others (Jamalus, 1988; Regelski,
1981).

The process of learning music in public schools has the main characteristic of flexibility, which means learning music must be able to accommodate the broad differences between student interests, learning styles, abilities, and flexibility in accommodating social changes that occur in society. The statement is in accordance with the basic philosophy of high school, namely: (1) as an important agent in the transmission and modification of culture; (2) fostering individuals to learn as early as possible in order to be able to develop rapidly over time and maturity; (3) implementing various techniques to help early teens become problem solvers and creative thinkers; (4) providing a balance in educational experience; (5) utilizing various patterns of learning organizations; (6) integrating all efforts and responsibilities of school personnel in developing educational programs; and (7) developing various technological assistance (Regelski, 1981).

Music as one of the learning materials in schools is a branch of art in the form of sound which contains elements of rhythm, melody, harmony, and timbre (Reed, \& Sidnell, 1978). Rhythm in music is a simple or double metric count which forms the basic pattern of melodic movements, whereas melody is a series of notes that form musical motifs and sentences. Harmony as part of the musical element is the harmony of sound, and timbre is the color or character of the sound. Complementing this understanding, Jamalus (1988) states that music is the result of sound art in the form of songs or musical compositions, which express the thoughts and feelings of the creator through the elements of music, namely rhythm, melody, harmony, form or structure song, and expression in a single unit.

Action-based music learning as an alternative comprehensively can only be achieved if the teacher is able to organize learning that can directly provide experiences to students (learning by doing). Therefore, as one of the efforts in developing teacher professionalism, this research aims 
to develop instruments for evaluating singing skills and playing musical instruments for music teacher candidates in public schools.

Previous research conducted by researchers revealed that, in the implementation of music learning in elementary schools, teachers experienced difficulties and obstacles in various ways, such as: (1) ability to translate the contents of competencybased educational unit curricula (KTSP); (2) the ability to optimize children's potential (active and creative); (3) applying appropriate learning methods; (4) utilizing the means and media of music learning; (5) utilizing the potential of the natural and cultural environment; and (6) developing forms of assessment that are appropriate to the characteristics of music learning (Utomo, 2013).

These findings are not much different from what happened in music teachers in junior high schools which showed that among music teachers there were still differences in priorities in setting goals and learning outcomes for their students. $20 \%$ of teachers think that students' skills in playing a musical instrument or singing become the main priority to be achieved in learning the art of music. While some other teachers that think the importance of music knowledge and its relation to various aspects of culture are $30 \%$. Even so, the majority $(50 \%)$ of teachers prioritize that the aim and results of learning the music are mastery of musical concepts and symbols obtained through various musical experiences (Utomo, 2013).

This finding was also strengthened when the researcher conducted a needs analysis activity in the development of teaching materials in the subject of music education study programs in the context of action learning-based. In this study, two important data were obtained: (1) the competencies needed by music teacher candidates; and (2) obstacles experienced by junior high school teachers in carrying out music learning in schools. The results of these studies indicate that an increase in the professionalism of music teachers conducted both when taking education (pre-service) or when after occupying the position of the teacher (in-service) is very necessary. In the context of educational institutions, Latifah's findings revealed that the learning process of existing musical instruments did not fully meet the needs of music teacher candidates in schools (Utomo, 2013; Latifah, 2012).

\section{METHODS}

The process of collecting data is done by interviews, questionnaires, assessment sheets and suggestions, task items, guidelines for observation and measurement. Data analysis was performed by combining qualitative and quantitative methods (Creswell, 2003; Tashskkori \& Teddlie, 2010). Qualitative technique was used to analyze and describe the data obtained through interviews, questionnaires, assessment sheets and suggestions obtained at the time of the study. While the quantitative analysis technique was carried out by the researcher when analyzing the data obtained through an assessment sheet and suggestions as well as the trial results of the developed assessment instruments. The quantitative analysis used to analyze the reliability of the instruments developed was the Intraclass Correlation Coefficient (ICC) test in the type of consistency definition and absolute agreement definition conducted using the SPSS program.

This research was conducted with a development research approach that was adapted from a design model developed by (Borg \& Gall, 1989) and (Cenamo \& Kalk, 2005). The research phase consists of two stages, namely: (1) the development phase in which consists of the activities of planning the assessment instrument model, designing, and testing of the developed assessment instruments; and (2) the dissemination stage carried out through seminar activities.

\section{RESULTS AND DISCUSSION}

Descriptions and Task Items of As- 
sessment Instruments of Music Teacher Candidates Competency in Singing and Playing Musical Instruments

The assessment instrument for teacher candidates' competency in singing and playing musical instruments developed in this study was a performance assessment model with a practice test technique for singing and playing musical instruments (Russell, 2014). The object of the study is a performance process based on the specified competency test material. The job description in this competency includes the teacher's competence in (1) reading the song notation with vocals; (2) reading song notation with melody based on the chosen musical instrument; (3) reading percus- sion notation with a drum set; (4) accompanying the song with a harmony musical instrument (keyboard or guitar); and (5) accompanying songs with percussion instruments (drum sets and drums). Based on the description of the task, the task items needed in the assessment of teacher competency consist of nine assignments. The formulation of the assignment items is sequentially described in the following table.

Based on Table 1 it can be explained that the task items number 1, 2, 3, 5a, 5b, and $5 \mathrm{c}$ are task items that emphasize the ability to read music notation in the form of number notation, and beam notation using vocal, melodic musical instruments, and

Table 1. Task Items of Assessment Instrument for Teachers' Competency in Singing and Playing Musical Instruments.

\begin{tabular}{|c|c|c|}
\hline Task Item & Task Item Formulation & Description \\
\hline 1 & $\begin{array}{l}\text { Read the following song notation and sing it ac- } \\
\text { cording to the song's characteristics }\end{array}$ & $\begin{array}{l}\text { Notation marked with bar } \\
3 / 4 \text { along the } 10 \text { segments of } \\
\text { the bars in number notation }\end{array}$ \\
\hline 2 & $\begin{array}{l}\text { Read the following song notation and sing it ac- } \\
\text { cording to the song's characteristics }\end{array}$ & $\begin{array}{l}\text { Notation marked with bar } \\
4 / 4 \text { along the } 10 \text { segments of } \\
\text { the bars in beam notation }\end{array}$ \\
\hline 3 & $\begin{array}{l}\text { Read the following song notation and play using } \\
\text { the melodic instrument of your choice according to } \\
\text { the characteristics of the song }\end{array}$ & $\begin{array}{l}\text { The song notation } G=1(1 \#) \\
\text { marked bar } 4 / 4 \text { along } 8 \text { bars } \\
\text { in beam notation. }\end{array}$ \\
\hline 4 & $\begin{array}{l}\text { Accompany the following song sentences using } \\
\text { the harmony musical instrument (keyboard or } \\
\text { guitar) in accordance with the characteristics of the } \\
\text { song and the chord progressions. }\end{array}$ & $\begin{array}{l}\text { The song notation } C=1 \\
\text { marked bar } 4 / 4 \text { along } 9 \text { bars } \\
\text { in number notation accom- } \\
\text { panied by cord progressions } \\
\text { and audio recordings. }\end{array}$ \\
\hline $5 a$ & $\begin{array}{l}\text { Read the following rhythmic notation and play } \\
\text { using the drum set in accordance with the charac- } \\
\text { teristics of the rhythmic pattern }\end{array}$ & $\begin{array}{l}\text { Rhythmic notation marked } \\
\text { bar } 4 / 4 \text { along } 4 \text { bars. }\end{array}$ \\
\hline $5 b$ & $\begin{array}{l}\text { Read the following rhythmic notation and play } \\
\text { using the drum set in accordance with the charac- } \\
\text { teristics of the rhythmic patterns. }\end{array}$ & $\begin{array}{l}\text { Rhythmic notation marked } \\
\text { bar } 3 / 4 \text { along } 4 \text { bars. }\end{array}$ \\
\hline $5 c$ & $\begin{array}{l}\text { Read the following rhythmic notation and play } \\
\text { using the drum set in accordance with the charac- } \\
\text { teristics of the rhythmic patterns. }\end{array}$ & $\begin{array}{l}\text { Rhythmic notation marked } \\
\text { bar } 2 / 4 \text { along } 4 \text { bars. }\end{array}$ \\
\hline 6 & $\begin{array}{l}\text { Accompany the following song sentences using a } \\
\text { rhythmic musical instrument (drum set) according } \\
\text { to the characteristics of the song. }\end{array}$ & $\begin{array}{l}\text { The song notation } C=1(1 \#) \\
\text { marked bar } 4 / 4 \text { along the } 9 \\
\text { bars in the number notation } \\
\text { with an audio recording. }\end{array}$ \\
\hline 7 & $\begin{array}{l}\text { Accompany the following song sentences using } \\
\text { a rhythmic musical instrument (drum) in accor- } \\
\text { dance with the characteristics of the song. }\end{array}$ & $\begin{array}{l}\text { The song notation } \mathrm{G}=1(1 \#) \\
\text { marked bar } 4 / 4 \text { along the } 18 \\
\text { bars in the number notation } \\
\text { with an audio recording. }\end{array}$ \\
\hline
\end{tabular}


rhythmic musical instrument. Whereas the task items number 4, 6, and 7 are task items which in addition to emphasizing the ability of teacher candidates to read music notation, also requires listening skills, and the ability to create music. The difference in characteristics between the two groups of task items has implications for the form of the assessment rubric which is used as an alternative in the assessment process. Based on the results of the trial and the revision process that has been carried out, aspects or indicators, and the rubric type of the assessment instruments of the competency for singing and playing musical instruments developed are explained in the Table 2.

Table 2 shows that the task items 1,2, $3,5 a, 5 b$, and $5 c$ which emphasize the ability to read music notation, the assessment process is done using analytic rubrics. Whereas in task items 4,6 , and 7 with the

Table 2. Task Item Formulation, Aspect or Indicator, and Types of Assessment Rubrics

\begin{tabular}{|c|c|c|c|}
\hline Task Item & Task Item Formulation & Aspect or Indicator & Types of Rubric \\
\hline 1 & $\begin{array}{l}\text { Read the following song notation } \\
\text { and sing it according to the song's } \\
\text { characteristics }\end{array}$ & $\begin{array}{l}\text { Accuracy of tone (pitch } \\
\text { and duration). } \\
\text { Fluency }\end{array}$ & Analytic \\
\hline 2 & $\begin{array}{l}\text { Read the following song notation } \\
\text { and sing it according to the song's } \\
\text { characteristics }\end{array}$ & $\begin{array}{l}\text { Accuracy of tone (pitch } \\
\text { and duration). } \\
\text { Fluency }\end{array}$ & Analytic \\
\hline 3 & $\begin{array}{l}\text { Read the following song notation } \\
\text { and play using the melodic instru- } \\
\text { ment of your choice according to the } \\
\text { characteristics of the song }\end{array}$ & $\begin{array}{l}\text { Accuracy of tone (pitch } \\
\text { and duration). } \\
\text { Fluency }\end{array}$ & Analytic \\
\hline $5 a$ & $\begin{array}{l}\text { Accompany the following song sen- } \\
\text { tences using the harmony musical } \\
\text { instrument (keyboard or guitar) in } \\
\text { accordance with the characteristics } \\
\text { of the song and the chord progres- } \\
\text { sions. }\end{array}$ & $\begin{array}{l}\text { Accuracy of a beat. } \\
\text { Fluency }\end{array}$ & Analytic \\
\hline $5 b$ & $\begin{array}{l}\text { Read the following rhythmic nota- } \\
\text { tion and play using the drum set in } \\
\text { accordance with the characteristics } \\
\text { of the rhythmic pattern }\end{array}$ & $\begin{array}{l}\text { Accuracy of the beat. } \\
\text { Fluency }\end{array}$ & Analytic \\
\hline $5 c$ & $\begin{array}{l}\text { Read the following rhythmic nota- } \\
\text { tion and play using the drum set in } \\
\text { accordance with the characteristics } \\
\text { of the rhythmic patterns. }\end{array}$ & $\begin{array}{l}\text { Accuracy of beat. } \\
\text { Fluency }\end{array}$ & Analytic \\
\hline 4 & $\begin{array}{l}\text { Read the following rhythmic nota- } \\
\text { tion and play using the drum set in } \\
\text { accordance with the characteristics } \\
\text { of the rhythmic patterns. }\end{array}$ & $\begin{array}{l}\text { Chord progression } \\
\text { Chord tone; Beat and } \\
\text { tempo } \\
\text { Accompaniment pattern } \\
\text { Variation; Improvisation } \\
\text { Dynamic; Fluency }\end{array}$ & Holistic \\
\hline 6 & $\begin{array}{l}\text { Accompany the following song } \\
\text { sentences using a rhythmic musical } \\
\text { instrument (drum set) according to } \\
\text { the characteristics of the song. }\end{array}$ & $\begin{array}{l}\text { Accompaniment pattern } \\
\text { Beat and tempo; Accom- } \\
\text { paniment variation; Fill in } \\
\text { Dynamic; Fluency }\end{array}$ & Holistic \\
\hline 7 & $\begin{array}{l}\text { Accompany the following song } \\
\text { sentences using a rhythmic musical } \\
\text { instrument (drum) in accordance } \\
\text { with the characteristics of the song. }\end{array}$ & $\begin{array}{l}\text { Accompaniment pattern } \\
\text { Beat and tempo } \\
\text { Accompaniment variation } \\
\text { Sound variation } \\
\text { Dynamic; Fluency }\end{array}$ & Holistic \\
\hline
\end{tabular}


many competency indicators available, the assessment process is more suitable to use a holistic rubric. The task items 1, 2, 3, 5a, $5 b$, and $5 c$ each have two aspects that are assessed using a rubric that will produce two scores of observations. On the other hand, the items 4, 6, and 7 of the competency indicators are assessed using a rubric holistic that will produce an observation score. Determination of aspects or indicators in the process of assessing music skills becomes an important decision in the preparation of the task items and rubric of the assessment. Because both of these represent the purpose of the assessment that is considered important (Zdzinski \& Barnes, 2002).

The Difference in Accuracy in the Assessment Process for Teacher Candidates in Singing and Playing Musical Instruments

The complexity of the observation objects in the performance assessment is very influential on the rater's accuracy and objectivity. Therefore, to have the right choice of the process of observing whether it should be analytic or holistic, it must pay attention to the characteristics of the observation object. A very detailed observation is certainly very good for an assessment of a performance. However, the many performance indicators that must be observed in detail, with limited observation time, make the foresight of the rater very difficult to maintain.

The results of trials conducted on the assessment model of teacher candidate competency in singing and playing musical instruments show that the results of observations of the performance process carried out with analytic models are more accurate when being compared with the holistic model. Analysis of the nine task items tested finds the reliability coefficient is 0.817 in the type of consistency definition and 0.810 in the type of absolute agreement definition. However, analysis conducted separately between task items using analytic rubric models $(1,2,3,5 a$, $5 b$, and $5 c)$ and holistic rubrics $(4,6$, and 7$)$ show that task items using analytic rubrics have the level of reliability better. The difference can be seen in the Table 3 .

The data in Table 3 shows that the number of the reliability coefficient of task items number 1, 2, 3, 5a, 5b and $5 \mathrm{c}$ with the analysis of consistency definition and absolute agreement definition of the reliability coefficient has fulfilled the specified criteria; 0.836 and 0.821 . On the other hand, the task item number 4,6 and 7 in the reliability coefficient are still below the specified criteria. The result of the analysis in the consistency definition test is less than 0.70 and in absolute agreement definition test is less than 0.60 . The results of the analysis carried out separately on task items number 4,6 and 7 show that the task item number 7 is a task item whose reliability coefficient does not meet the specified criteria. The result of the analysis in the consistency definition test is 0.547 (less than 0.70) and in the absolute agreement definition test is 0.277 (less than 0.60).

After evaluating the results of the

Table 3. Reliability of Competency Test Instruments for Teachers Candidates in Singing and Playing Musical Instruments Based on Rubric Characteristics

\begin{tabular}{ccccc}
\hline \multirow{2}{*}{ Task Item } & \multicolumn{3}{c}{ Intraclass Correlation Coefficient (ICC) } \\
\cline { 2 - 5 } & \multicolumn{2}{c}{ Single Measures } & \multicolumn{2}{c}{ Average Measures } \\
\cline { 2 - 5 } & Consistency & $\begin{array}{c}\text { Absolute } \\
\text { Agreement }\end{array}$ & Consistency & $\begin{array}{c}\text { Absolute } \\
\text { Agreement }\end{array}$ \\
\hline 1, 2, 3, 5a, 5b dan 5c & 0.836 & 0.821 & 0.939 & 0.932 \\
4,6 , dan 7 & 0.629 & 0.529 & 0.836 & 0.771 \\
4 & 0.725 & 0.707 & 0.888 & 0.879 \\
6 & 0.770 & 0.733 & 0.909 & 0.892 \\
7 & 0.547 & 0.277 & 0.784 & 0.534 \\
\hline
\end{tabular}


Table 4. The Increase of Reliability Coefficient in the Task Item Group for Teachers' Competency in singing and Playing Musical Instruments

\begin{tabular}{ccccc}
\hline \multirow{2}{*}{ Measures } & \multicolumn{3}{c}{ Intraclass Correlation Coefficient (ICC) } \\
\cline { 2 - 5 } & \multicolumn{2}{c}{ Prior Remedial } & \multicolumn{2}{c}{ After Remedial } \\
\cline { 2 - 5 } & Consistency & $\begin{array}{c}\text { Absolute } \\
\text { Agreement }\end{array}$ & Consistency & $\begin{array}{c}\text { Absolute } \\
\text { Agreement }\end{array}$ \\
\hline Single Measures & 0.783 & 0.775 & 0.817 & 0.810 \\
Average Measures & 0.915 & 0.912 & 0.931 & 0.928 \\
\hline
\end{tabular}

competency test with the rater and revising the rubric of task item number 7 , only then can achieve the expected results. Task number 7 which was originally the result of the consistency definition test was 0.547 and in the absolute agreement definition test was 0.277 , it increased to 0.726 in the consistency definition test and 0.700 in the absolute agreement definition test.

The increase in the reliability coefficient of task item number 7 has an effect on the increase in the reliability coefficient of the task item group of the teacher competency in singing and playing musical instruments. It was proven before the rubric was improved, the reliability coefficient (single measures) of the task item group of the teacher competency in singing and playing musical instruments in the type of consistency definition test was 0.783 and in the type of absolute agreement definition test was 0.775 . After the rubric has been improved on task number 7 , the reliability coefficient increased to 0.817 in the type of consistency definition and 0.810 in the type of absolute agreement definition. The increase in the reliability coefficient of the task items of the teacher's competency in singing and playing musical instruments is summarized in the Table 4.

The difference in the level of consistency obtained based on the results of the reliability test between items using analytic rubric and holistic rubric is very reasonable. The level of complexity of aspects or indicators of competency in the skills of singing and playing musical instruments and measurement criteria are important components that need to be considered. Nevertheless, the preparation of an adequate rubric of the two types of task items can harmonize the results of the assessment conducted. So that the assessment instruments developed reliably and fairly (Carpente \& Gattino, 2018; Guntur et al., 2014).

\section{CONCLUSION}

The instruments for evaluating the competency in singing and playing musical instruments can be applied in an effort to increase the professionalism of music teachers in institutions that prepare educational staff. Substantial and structured application can be integrated in relevant courses.

The development of task items in singing and playing musical instruments for teacher candidates can be done by considering the complexity of the objectives of the assessment and the observation object. Therefore, the performance process that is not complex and requires detailed information on every aspect can be done using analytic rubrics as a measurement guide. On the other hand, when observing every performance indicator in a complex performance process, it is suggested to use and implement holistic rubric as the measurement standard and guide.

To develop the task items and assessment rubrics for singing and playing musical instrument skills, the reliability testing process can be carried out using the Intraclass Correlation Coefficient (ICC) test of the type of consistency definition and absolute agreement definition involving three raters. Based on the results of trials that have been carried out through this analysis, it is obtained information that gives clues to the quality of the task 
items, aspects, indicators, scoring, and assessment criteria. As a follow-up, studies are still needed specifically to examine the characteristics of the task items, aspects, indicators, the range of scoring, and assessment criteria in performances in music learning in public schools.

\section{ACKNOWLEDGMENT}

This article is part of the findings of research funded by the Directorate of Research and Community Service (DRPM) Kemenristekdikti. Therefore, we express our gratitude because, through this research program we can conduct research in the field of assessment for the benefit of the professional development of the music teacher at our institution.

\section{REFERENCES}

Borg, W. R. \& Gall, M. (1989). Education Research: An Introduction (Fifth Edit). London: Longman.

Carpente, J. A., \& Gattino, G. S. (2018). Interrater Reliability on Individual MusicCentered Assessment Profil for Neurodevelopmental Disorder (IMCAP-ND0 for Autism Spectrum Disorder. Nordic Journal of Music Therapy, 27(4), 297-311.

Cenamo, K, \& Kalk, D. (2005). Real World Instructional Design. Boston: Thomson Learning, Inc.

Creswell, J. W. (2003). Research Design: Qualitative, Quantitative, and Mixed Methods Approaches (Second Edi). New York: SAGE Publications Ltd.

Fitzsimons, P. (1997). The Governance of Teacher Competency Standards in New Zealand. Australian Journal of Teacher Education, 22(2), 2-7.

Guntur, G., Sukadiyanto, S., \& Mardapi, D. (2014). Pengembangan asesmen hasil belajar penjasorkes siswa sma pada permainan bolavoli. Jurnal Penelitian dan Evaluasi Pendidikan, 18(1), 13-29.

Jamalus. (1988). Pembelajaran Musik Melalui Pengalaman Musik. Jakarta: Dirjendikti Depdikbud.

Latifah, D. (2012). Evaluasi Mata Kuliah Piano untuk Menghasilkan Guru Musik Di Sekolah. Jurnal Penelitian Dan Evaluasi Pendidikan, 16(2), 457-473.

Reed, H. O, \& Sidnell, R. (1978). Materials of Music Composition. Boston: AddisonWesley Educational Publiser Inc.

Regelski, T. A. (1981). Teaching General Music. Boston: Collier Macmillan Publishers.

Russell, J. A. (2014). Assessment in Instrumental Music. Online Publication. https:// doi.org/10.1093/oxford$\mathrm{hb} / 9780199935321.013 .100$

Sinaga, S., \& Utomo, U. (2010). Kreativitas Guru dalam Pembelajaran Seni Musik di SMP (Studi Kasus pada Pelaksanaan Pembelajaran Seni Musik di SMP Kota Semarang). Semarang: Universitas Negeri Semarang.

Tashskkori, A. \& Teddlie, C. (2010). Mixed Methodology: Mengkombinasikan Pendekatan Kualitatif dan Kuantitatif. Jakarta: Pustaka Pelajar.

Utomo, U. (2013). Analisis Kebutuhan Guru Seni Musik dalam Konteks Pelaksanaan Pembelajaran Berbasis Action Learning di Sekolah. Harmonia: Journal of Arts Research and Education, 13(2), 108-117.

Utomo, U., \& Ardiyarta, T. (2013). Pengembangan Instrumen Penilaian Unjuk Kerja (Performance Assessment) Kompetensi Ekspresi dan Kreasi Musik di Sekolah Menengah Pertama (SMP). Harmonia: Journal of Arts Research and Education, 13(1), 1-9.

Utomo, U., \& Sinaga, S. S. (2009). Pengembangan Materi Pembelajaran Seni Musik Berbasis Seni Budaya Berkonteks Kreatif, Kecakapan Hidup, dan Menyenangkan bagi Siswa SD/MI. Harmonia: Journal of Arts Research and Education, 9(2), 1-13.

Yoseph, W. (2009). Implementasi Kurikulum Tingkat Satuan Pendidikan (KTSP): Studi Kasus dalam Pembelajaran Musik di SMA Citischool Semarang. Harmonia Jurnal Pengetahuan Dan Pemikiran Seni, 9(3), 49-57.

Zamroni, Z. (2000). Pendidikan untuk Demokrasi: Tantangan Menuju Civil Society. Semarang: Bigraf Publishing.

Zdzinski, S. F., \& Barnes, G. V. (2002). Development and validation of a string performance rating scale. Journal of Research in Music Education, 50(3), 245-255. 